\title{
A review on catalytic \& non-catalytic bio-oil upgrading in supercritical fluids
}

\author{
Sainab Omar, Yang Yang, Jiawei Wang (ه) \\ Chemical Engineering and Applied Chemistry, Aston University, Birmingham, B4 7ET, UK
}

(C) The Author(s) 2020. This article is published with open access at link.springer.com and journal.hep.com.cn

\begin{abstract}
This review article summarizes the key published research on the topic of bio-oil upgrading using catalytic and non-catalytic supercritical fluid (SCF) conditions. The precious metal catalysts $\mathrm{Pd}, \mathrm{Ru}$ and $\mathrm{Pt}$ on various supports are frequently chosen for catalytic bio-oil upgrading in SCFs. This is reportedly due to their favourable catalytic activity during the process including hydrotreating, hydrocracking, and esterification, which leads to improvements in liquid yield, heating value, and $\mathrm{pH}$ of the upgraded bio-oil. Due to the costs associated with precious metal catalysts, some researchers have opted for non-precious metal catalysts such as acidic HZSM-5 which can promote esterification in supercritical ethanol. On the other hand, SCFs have been effectively used to upgrade crude bio-oil without a catalyst. Supercritical methanol, ethanol, and water are most commonly used and demonstrate catalyst like activities such as facilitating esterification reactions and reducing solid yield by alcoholysis and hydrolysis, respectively.
\end{abstract}

Keywords bio-oil, upgrading, supercritical, review

\section{Introduction}

In recent years, the world has been facing an energy crisis due to a combination of several factors including the depletion of fossil fuels, accelerated population growth, increase in global energy demand, and crude oil price fluctuations. Furthermore, the extensive use of fossil fuels has led to climate change and global warming. These global issues have motivated research into alternative energy technologies, renewable resources, and more sustainable techniques for energy generation.

Biomass can be utilised as a renewable feed for

Received January 3, 2020; accepted March 7, 2020

E-mail: j.wang23@aston.ac.uk conversion into gaseous, liquid, and solid biofuels [1]. Biomass is any biodegradable material of biological origin excluding fossilized material or peat [2]. Fast pyrolysis is a thermal conversion technique that decomposes biomass in the absence of oxygen [1]. Pyrolysis liquid (bio-oil) is produced under moderate temperature $\left(\sim 500^{\circ} \mathrm{C}\right)$ and short vapor residence times $(\sim 1 \mathrm{~s})$ [1]. Fast pyrolysis for liquid production is especially interesting as the process directly converts biomass to high yield liquid of up to $75 \mathrm{wt}-\%$ whilst keeping gas and char by-products at low yields of $12 \mathrm{wt}-\%$ and $13 \mathrm{wt}-\%$ [3]. Common feedstocks for pyrolysis oil production include wood, bagasse, rice straw, switchgrass and wheat straw [4]. The liquid biofuel, commonly known as crude bio-oil, has generated growing interest as it can be used for energy, chemicals, or as an energy carrier. However, the properties of crude pyrolysis oil such as high acidity and viscosity and high oxygen and water contents lead to detrimental effects during application including corrosion to metal components, instability during storage and reduced heating value. This affects the direct use of crude bio-oil and its assimilation into existing liquid fuel infrastructures.

Table 1 compares select characteristics of wood-derived crude bio-oil and heavy petroleum fuel oil $[1,5,6]$. The properties of crude bio-oil such as low heating value, high moisture, and oxygen content lead to unfavourable effects during application including poor stability and immiscibility with hydrocarbons. This inhibits the direct use of crude bio-oil and its assimilation into existing fuel infrastructures. Thus, upgrading the crude bio-oil is necessary. This involves reducing or eliminating one or more of its undesirable properties, ultimately improving its quality before practical application. Among the various upgrading technologies, the use of supercritical fluids (SCFs) has proved promising for bio-oil upgrading.

In the past decade, extensive research has been conducted on bio-oil upgrading in SCFs. However, although several reviews have been done on the topic of bio-oil upgrading; there are no reviews to date, 
Table 1 Comparison of wood-derived crude bio-oil and heavy petroleum fuel oil $[1,5,6]$

\begin{tabular}{lcc}
\hline Items & $\begin{array}{c}\text { Wood-derived } \\
\text { crude bio-oil }\end{array}$ & $\begin{array}{c}\text { Heavy petroleum } \\
\text { fuel oil }\end{array}$ \\
\hline Moisture content /wt-\% & 0.1 & 25 \\
$\mathrm{pH}$ & - & 2.5 \\
Specific gravity & 0.94 & 1.2 \\
$\mathrm{C} / \mathrm{wt}-\%$ & 85 & 56 \\
$\mathrm{H} / \mathrm{wt}$ \% & 11 & 6 \\
O/wt-\% & 1 & 38 \\
$\mathrm{~N} / \mathrm{wt}-\%$ & 0.3 & $0-0.1$ \\
Higher heating value/(MJ $\left.\cdot \mathrm{kg}^{-1}\right)$ & 40 & 17 \\
Viscosity/(mPa·s) & $40-100$ & 180 \\
Solids/wt-\% & 1 & 0.1 \\
\hline
\end{tabular}

summarizing the research on supercritical fluid (SCF) upgrading of bio-oil. The key words; bio-oil, upgrading, review, were used to identify a total of 19 research papers. When the search terms bio-oil, upgrading, SCFs, review, were used no records were identified. This work aims to review the conducted research and current progress on catalytic and non-catalytic bio-oil upgrading in SCFs.

\section{Supercritical fluids}

A SCF is defined as the state of a compound, mixture, or element above its critical temperature $\left(T_{\mathrm{c}}\right)$ and critical pressure $\left(P_{\mathrm{c}}\right)$ but lower than the pressure necessary to condense it into a solid [7]. The critical point marks the end of the liquid-vapour coexistence and only a single homogenous fluid phase can exist in the supercritical region [7]. Thus, the properties of SCFs are frequently described as an intermediate between those of a liquid and a gas, as shown in Table $2[7,8]$.

Table 2 compares the selected physical properties of a liquid, gas, and SCF [8]. The density of a SCF approximates to that of a liquid while the viscosity and diffusivity are close to that of a gas. The liquid-like density of SCFs allows many materials to be solubilized to a level significantly greater than that predicted by ideal gas considerations [7]. Due to the high compressibility of fluids near the critical point, their density is highly sensitive to small changes in pressure and temperature
[7,8]. Many solvent properties such as dissolving power and dielectric constant are directly related to bulk density, and therefore exhibit a similar pressure dependence [7]. These characteristics are unique to SCFs and enable the opportunity to tune the reaction environment to optimize the reaction rate and selectivity [7]. The tunable solvent properties are one of the many interesting features associated with SCFs and forms the basis for its application in modern chemical synthesis.

The advantages of using SCFs as reaction media for chemical synthesis rather than liquids have been broadly organised into four categories by Jessop and Leitner and summarised in Table 3.

\section{Catalytic bio-oil upgrading in SCFs}

The application of catalysts during bio-oil treatment processes improves the reaction rates and bio-oil yield. However, homogenous catalytic reactions lead to expensive and energy-intensive separation processes [9]. Likewise, concerns for heterogeneous catalytic reactions include long reaction times and expensive catalyst [9]. Thus, researchers have developed alternative methods such as the addition of SCFs to overcome the limitations of catalytic bio-oil upgrading processes. Figure 1 illustrates the working principles of the bio-oil upgrading in SCF process.

The ideal catalyst for bio-oil upgrading is highly active, eliminates the oxygen in the bio-oil, promotes high yield, and forms no coke deposits [10]. Studies of bio-oil upgrading by hydrodeoxygenation (HDO) have used sulfided NiMo and CoMo catalysts [10]. However, these catalysts lead to sulfur contamination in the bio-oil and rapid catalyst deactivation [11]. Thus, precious metal catalysts such as supported $\mathrm{Pd}, \mathrm{Pt}$, and $\mathrm{Ru}$ have been utilised for catalytic upgrading experiments [10,11]. These catalysts promote increased HDO and higher yields compared to traditional hydrotreatment catalysts [10].

\subsection{Precious metals catalysts - palladium}

Palladium is one of the most frequently used active metal catalysts for bio-oil upgrading due to its high hydrotreating capability [12]. Among the catalysts used for bio-oil upgrading, $\mathrm{Pd}$ is highly active during the deoxygenation and hydrogenation of unsaturated carbon-carbon bonds

Table 2 Comparing the properties of liquid, gas, and SCFs ${ }^{\text {a) }}$

\begin{tabular}{lccc}
\hline Physical Property & Liquid ${ }^{\text {b) }}$ & SCF & Gas ${ }^{\text {b) }}$ \\
\hline Density $/\left(\mathrm{kg} \cdot \mathrm{m}^{-3}\right)$ & $600-1600$ & $200-500$ & $0.6-2$ \\
Dynamic viscosity $/(\mathrm{mPa} \cdot \mathrm{s})$ & $0.2-3$ & $0.01-0.03$ & $0.01-0.3$ \\
Diffusion coefficient $/\left(\times 10^{6} \mathrm{~m}^{2} \cdot \mathrm{s}^{-1}\right)$ & $0.0002-0.002$ & 0.07 & $10-40$ \\
\hline
\end{tabular}

a) Data from [8]; b) ambient conditions. 
Table 3 Advantages of using SCFs as reaction media for chemical synthesis [7]

\begin{tabular}{|c|c|c|}
\hline Category & Advantage & SCF type \\
\hline Environment & $\begin{array}{c}\text { Do not contribute to smog } \\
\text { Do not damage ozone layer } \\
\text { No acute ecotoxicity } \\
\text { No liquid wastes }\end{array}$ & $\begin{array}{c}\text { Most } \\
\text { Most } \\
\mathrm{CO}_{2}, \mathrm{H}_{2} \mathrm{O} \\
\mathrm{CO}_{2} \text { and other volatile } \mathrm{SCFs}\end{array}$ \\
\hline Health and safety & $\begin{array}{l}\text { Noncarcinogenic } \\
\text { Nontoxic } \\
\text { Non-flammable }\end{array}$ & $\begin{array}{c}\text { Most (but not } \mathrm{C}_{6} \mathrm{H}_{6} \text { ) } \\
\text { Most (but not } \mathrm{HCI}, \mathrm{HBr}, \mathrm{HI}, \mathrm{NH}_{3} \text { ) } \\
\mathrm{CO}_{2}, \mathrm{~N}_{2} \mathrm{O}, \mathrm{H}_{2} \mathrm{O}, \mathrm{Xe}, \mathrm{Kr}, \mathrm{CHF}_{3}\end{array}$ \\
\hline Process & $\begin{array}{c}\text { No solvent residues } \\
\text { Facile separation of products } \\
\text { High diffusion rates } \\
\text { Low viscosity } \\
\text { Adjustable solvent power } \\
\text { Adjustable density } \\
\text { Inexpensive }\end{array}$ & $\begin{array}{c}\mathrm{CO}_{2} \text { and other volatile SCFs } \\
\mathrm{CO}_{2} \text { and other volatile SCFs } \\
\text { All } \\
\text { All } \\
\text { All } \\
\text { All } \\
\mathrm{CO}_{2}, \mathrm{H}_{2} \mathrm{O}, \mathrm{NH}_{3}, \mathrm{Ar} \text {, hydrocarbons }\end{array}$ \\
\hline Chemical & $\begin{array}{c}\text { High miscibility with gases } \\
\text { Variable dielectric constant } \\
\text { High compressibility } \\
\text { High diffusion rates }\end{array}$ & $\begin{array}{c}\text { All } \\
\text { The polar SCFs } \\
\text { All } \\
\text { All }\end{array}$ \\
\hline
\end{tabular}

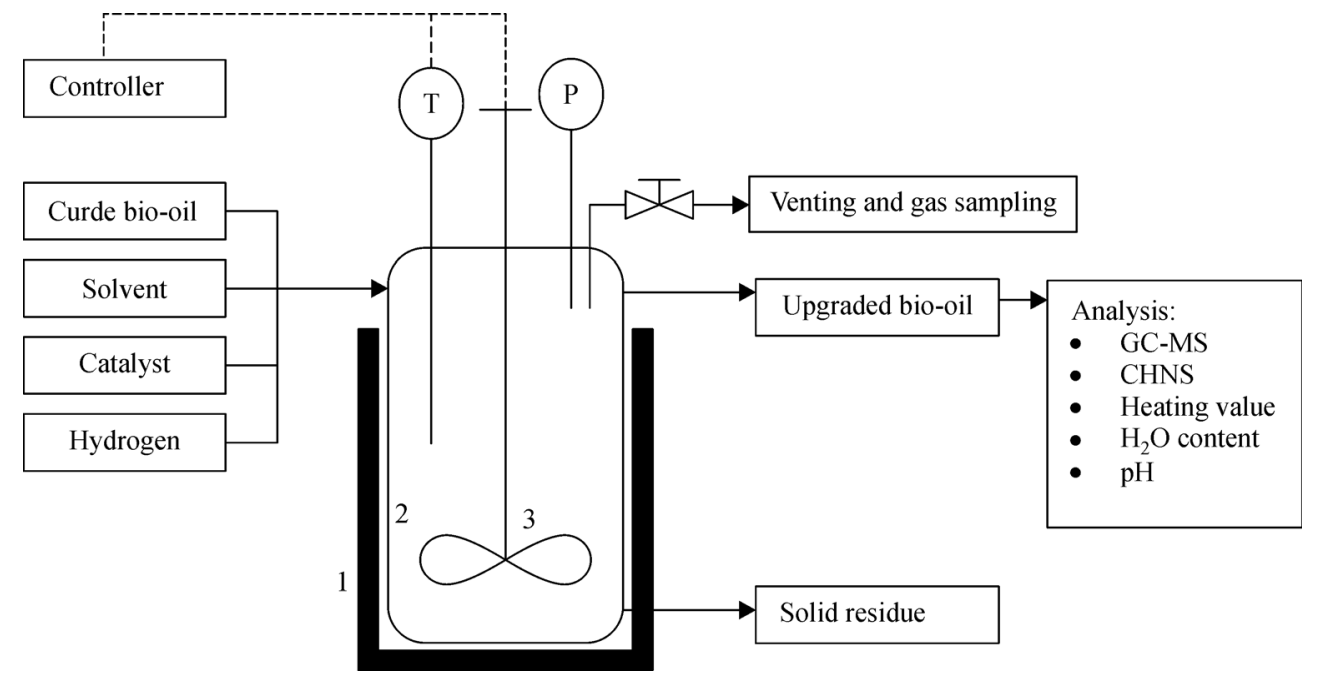

Fig. 1 Schematic diagram of bio-oil upgrading in SCF experiments. (1) heater, (2) autoclave, (3) stirrer, T: temperature detector, P: pressure gauge.

[11]. Pd is also recognised for its effectiveness in converting fatty acids to alkanes, this improves the storage stability of the bio-oil and enhances its energy density [13].

Chen et al. compared and studied the stability of various catalysts $(\mathrm{Ru} / \mathrm{C}, \mathrm{Pd} / \mathrm{C}, \mathrm{Pt} / \mathrm{C}, \mathrm{Ru} / \mathrm{HZSM}-5)$ in bio-oil upgrading with supercritical ethanol [14]. The results showed the highest heating value, $\mathrm{pH}$ value and lowest water content of upgraded bio-oil in supercritical ethanol was achieved over $\mathrm{Pd} / \mathrm{C}$. The improvement of these properties in the bio-oil increases its potential for application as an alternative fuel. Similarly, Tang et al. used Pd based catalysts for bio-oil upgrading in supercritical ethanol. In this study, upgrading crude bio-oil in supercritical ethanol using $\mathrm{Pd} / \mathrm{SO}_{4}{ }^{2-} / \mathrm{ZrO}_{2} / \mathrm{SBA}-15$ (PdSZr) generated a trace amount of tar or coke while with
$\mathrm{SO}_{4}{ }^{2-} / \mathrm{ZrO}_{2} / \mathrm{SBA}-15$ (SZr) catalyst, or upgrading without any catalyst, a significant amount of tar and coke was formed [12]. Hence, PdSZr effectively performed as a hydrotreating catalyst and inhibited polymerisation and condensation reactions. Also, the highest heating value, oil yield, and the lowest water content was obtained with the PdSZr catalyst [12].

Zhang et al. investigated bio-oil upgrading over supported Pt and Pd catalysts in supercritical methanol/ ethanol [15]. Like Tang et al., the findings showed Pd, with more dissolved active hydrogen, had a higher hydrogenation activity for large molecular-weight compounds, thus inhibited unstable polymers to form solid products. Moreover, although both $\mathrm{Pt}$ and Pd upgraded bio-oils exhibited complete absence of acids, the Pd/HZSM-5 
treated oil contained higher esters compared to the Pt/HZSM-5 oil, which may indicate higher esterification was achieved with the former catalyst.

Bai et al. examined the activity of various catalysts on the processing of pre-treated algal oil in supercritical water (SCW) [16]. In this study, $\mathrm{Pd} / \mathrm{C}$ generated higher oil yield and lower coke yield than Pt/C. Similarly, Zhang et al. examined the effects of several different commercially available catalysts on biocrude in subcritical water [17]. The results showed $\mathrm{Pd} / \mathrm{C}$ produced bio-oil had a higher $\mathrm{H} / \mathrm{C}$ content, lower sulfur, and water content than $\mathrm{Pt} / \mathrm{C}$ as well as lower ash content than both $\mathrm{Ru} / \mathrm{C}$ and $\mathrm{Pt} / \mathrm{C}$. Reduced sulfur, water, and ash content in bio-oil are desirable as these components can lead to catalyst poisoning, reduced heating value, and a phase-separated oil, respectively. However, Duan and Savage suggested $\mathrm{Pd} / \mathrm{C}(5 \%)$ and $\mathrm{Pt} / \mathrm{C}(5 \%)$ have similar catalytic activity towards upgrading of algal bio-oil in SCW despite their different metal dispersion, specific surface area and micropore volume [13].

\subsection{Precious metals catalysts - ruthenium}

Ruthenium is a commonly used active metal catalyst for bio-oil upgrading due to its high hydrocracking capabilities [18]. This has several advantages including increasing the oil yield, and heating value whilst limiting solid production. Tang et al. found bio-oil upgraded in supercritical ethanol and $\mathrm{Ru}$ catalyst obtained significantly lower solid residue, and higher oil yield and heating value than with $\mathrm{ZrO}_{2} / \mathrm{SBA}-15, \mathrm{SO}_{4}{ }^{2-} / \mathrm{ZrO}_{2} / \mathrm{SBA}-15$, or supercritical ethanol alone (i.e., catalyst-free conditions) [18]. Ru based catalysts also provide higher hydrocracking than other commonly used precious metal catalysts. Chen et al. found $\mathrm{Ru} / \mathrm{C}$ and $\mathrm{Ru} / \mathrm{HZSM}-5$ generated an upgraded bio-oil with higher oil content than $\mathrm{Pd} / \mathrm{C}$ and $\mathrm{Pt} / \mathrm{C}$ treated oils [14]. Likewise, Bai et al. found among all the single components and precious metal catalysts, $\mathrm{Ru} / \mathrm{C}$ upgraded oil exhibited the highest oil yield and the highest heating value $\left(45.1 \mathrm{MJ} \cdot \mathrm{kg}^{-1}\right)$; slightly higher than that of petroleum diesel $\left(44.8 \mathrm{MJ} \cdot \mathrm{kg}^{-1}\right)$ [16]. Yao et al. found introducing $\mathrm{Ru}$ into acidic catalysts promoted pyrolytic lignin hydrocracking and inhibited polymerization and condensation, this caused the oil yield to increase significantly [19]. Similarly, Duan et al. reported the presence of $\mathrm{Ru} / \mathrm{C}$ during bio-oil upgrading in SCW led to reduced coke formation due to the catalyst promoting hydrogenation of the coke precursor, and inhibiting polymerisation and condensation reactions [20]. Finally, Ahmadi et al. compared the effects of CoMo and $\mathrm{Ru} / \mathrm{C}$ catalyst and reported the latter produced the highest oil yield and negligible coke formation $(<1 \mathrm{wt}-\%)$ [21].

$\mathrm{Ru}$ based catalysts are also recognised for improving the elemental properties of bio-oil through hydrogenation, deoxygenation and denitrogenation reactions. Zhang et al. found $\mathrm{Ru} / \mathrm{C}$ was the most active catalyst for the upgrading of biocrude compared to 11 different catalysts including $\mathrm{Pt} / \mathrm{C}$ and $\mathrm{Pd} / \mathrm{C}$ [17]. Moreover, contrary to findings from Bai et al., Zhang et al. reported $\mathrm{Ru} / \mathrm{C}$ was the only catalyst capable of promoting denitrogenation [16,17]. Additionally, the oil produced with this catalyst exhibited the lowest sulfur content, highest hydrocarbon content, and the highest heating value. The catalyst screening study by Bai et al. also found $\mathrm{Ru} / \mathrm{C}$ showed the best performance for deoxygenation by generating an upgraded oil with the lowest $\mathrm{O} / \mathrm{C}$ molar ratio compared to 15 different catalysts including $\mathrm{Pd}$ and $\mathrm{Pt}$ [16]. Additionally, the $\mathrm{Ru} / \mathrm{C}$ produced upgraded oil contained the highest carbon content.

Duan et al. reported on the high performance of $\mathrm{Ru} / \mathrm{C}$ in hydrogenation reactions, as a result, $\mathrm{Ru} / \mathrm{C}$ upgraded bio-oil had the lowest unsaturated hydrocarbon content and highest aromatic content [20]. Similarly, Chen et al. found the highest relative content of desired products was achieved over $\mathrm{Ru} / \mathrm{C}$ and $\mathrm{Ru}$ exhibited higher hydrogenation ability than $\mathrm{Pd}$ and $\mathrm{Pt}$ which might be the reason for the better upgrading performance of $\mathrm{Ru} / \mathrm{C}$ [14].

$\mathrm{Oh}$ et al. investigated the effects of $\mathrm{Ru} / \mathrm{C}$ and $\mathrm{Pt} / \mathrm{C}$ catalysts on the HDO of bio-oil [22]. Although both $\mathrm{Ru} / \mathrm{C}$ and $\mathrm{Pt} / \mathrm{C}$ treated oils obtained complete removal of acid content, the Total Acid Number (TAN) of the $\mathrm{Ru} / \mathrm{C}$ upgraded oil decreased by $59 \%$ of the original bio-oil whilst $\mathrm{Pt} / \mathrm{C}$ decreased the TAN by $54 \%$. Similarly, Bai et al. found $\mathrm{Ru} / \mathrm{C}$ upgraded oil had the lowest TAN compared to several catalysts including $\mathrm{Pt} / \mathrm{C}$ and $\mathrm{Pd} / \mathrm{C}$ [16]. Bio-oil with TAN above the American Society of Testing Materials (ASTM) specification (0.50 $\mathrm{mg} \mathrm{KOH} \cdot \mathrm{g}^{-1}$ according to the ASTM D 6751-07a) may lead to operational problems and cause corrosion during storage [23]. Thus, reducing the acidity of bio-oil is essential to enable the storage and transportation of bio-oil.

Interestingly, Bai et al. found a combination of $\mathrm{Ru} / \mathrm{C}$ and Raney Ni performed better during bio-oil upgrading than either catalyst alone [16]. Likewise, Xu et al. examined the effect of two-component catalyst mixtures, with $\mathrm{Ru} / \mathrm{C}$ as the baseline catalysts, on the upgrading of pre-treated algal oil in SCW [24]. The authors reported the catalyst mixture provided favourable advantages to bio-oil upgrading such as higher hydrogenation. However, the catalyst mixtures were less effective for deoxygenation compared to $\mathrm{Ru} / \mathrm{C}$ alone. In addition, ruthenium is very expensive and difficult for regeneration, thus not a viable catalyst for bio-oil upgrading on a large scale.

\subsection{Precious metals catalysts - platinum}

Among the noble metal catalysts commonly used in bio-oil upgrading, $\mathrm{Pt}$ is one of the most active catalysts [25]. Pt is a frequently selected catalyst due to its hydrotreating capability, effectiveness for decarboxylation of fatty acids, enhancing the oil stability, and its high durability 
and thermal resistance [22,23]. Bio-oils upgraded in $\mathrm{Pt}$ based catalysts have been shown to exhibit a high abundance of hydrocarbons, and lead to a free flowing liquid product oil $[23,25]$.

As previously mentioned, Zhang et al. conducted bio-oil upgrading studies using $\mathrm{Pt}$ and $\mathrm{Pd}$ catalysts and found Pd/HZSM-5 treated oil contained higher esters compared to the Pt/HZSM-5 oil under supercritical methanol [15]. However, bio-oil upgraded in $\mathrm{Pt} / \mathrm{SZr}$ and supercritical methanol/ethanol and bio-oil upgraded in Pt/HZSM-5 and supercritical ethanol all exhibited higher ester content than with Pd based catalyst. Similarly, the catalyst screening study by Chen et al. showed bio-oil upgraded over $\mathrm{Pt} / \mathrm{C}$ exhibited the highest relative content of esters compared to various catalysts including $\mathrm{Pd} / \mathrm{C}$ and $\mathrm{Ru} / \mathrm{C}$ [14]. The high presence of esters in upgraded bio-oil is favourable as it corresponds to the reduction in acids due to esterification reactions which leads to less corrosive and more stable biooil.

Moreover, the changes in the TAN and $\mathrm{pH}$ of the bio-oil can be used to examine the catalysts ability to promote acid decreasing reactions such as esterification during upgrading processes. Bai et al. showed $\mathrm{Pt} / \mathrm{C}$ upgraded oil had a lower TAN than $\mathrm{Pd} / \mathrm{C}$ upgraded oil. Hence, the former catalysts proved more effective for reducing the acidity of biocrude oil [16]. However, Chen et al. showed $\mathrm{Pd} / \mathrm{C}$ upgraded oil exhibited a higher $\mathrm{pH}$ than $\mathrm{Pt} / \mathrm{C}$ treated oil due to the higher relative content of acids in the latter [14]. Nevertheless, Pt based catalysts have been shown to increase the $\mathrm{pH}$ of crude bio-oil in many studies. For example, Dang et al. demonstrated Pt/SZr catalyst can increase the $\mathrm{pH}$ of crude pyrolysis oil by up to $83 \%$ under supercritical ethanol [26]. Likewise, Li et al. demonstrated bio-oil upgraded over $\mathrm{PtNi} / \mathrm{MgO}$ in supercritical methanol increased in $\mathrm{pH}$ value from 2.9 to 6.7 [27]. Overall, these findings may be an indication of Pt based catalyst's ability to catalyse esterification reactions, hence decrease the acidity of crude bio-oil during supercritical upgrading processes.

Several studies have shown Pt catalysts effectiveness for increasing the oil yield. The bio-oil HDO study by Oh et al. found the highest oil yield can be obtained with Pt based catalyst compared to the Ru based catalyst [22]. Similarly, Chen et al. showed Pt/C upgraded oil had a higher oil content than $\mathrm{Pd} / \mathrm{C}$ upgraded oil [14]. Moreover, both Bai et al. and Zhang et al. showed sulfided $\mathrm{Pt} / \mathrm{C}$ upgraded oil in supercritical and subcritical water respectively generated higher oil yield than with $\mathrm{Pd} / \mathrm{C}[16,17]$. Whereas non-sulfided $\mathrm{Pt} / \mathrm{C}$ treated oil obtained comparatively lower oil yield. These findings indicated the sulfide form of this catalyst is favourable for realising higher upgraded oil yields $[16,17,24]$. However, the results from both Bai et al. and Zhang et al. showed the carbon and hydrogen content, and higher heating value (HHV) of the sulfided $\mathrm{Pt} / \mathrm{C}$ upgraded oil was lower than that of the $\mathrm{Pt} / \mathrm{C}$ upgraded oil
$[16,17]$. Hence, the authors concluded pre-sulfiding the $\mathrm{Pt} / \mathrm{C}$ does not cause any significant variations in the characteristics of the upgraded oil $[16,17,28]$.

Zhang et al. also reported that $\mathrm{Pt} / \mathrm{C}$ showed the best performance for HDO and biocrude treated with this catalyst exhibited higher heating value, carbon content, and lower nitrogen content than with $\mathrm{Pd} / \mathrm{C}$ catalyst [17]. Similarly, Bai et al. found $\mathrm{Pt} / \mathrm{C}$ upgraded oil had lower $\mathrm{O} / \mathrm{C}$ ratio, nitrogen content, higher $\mathrm{H} / \mathrm{C}$ ratio, and heating value than several catalysts including $\mathrm{Pd} / \mathrm{C}$ [16]. Interestingly, $\mathrm{Oh}$ et al. found the $\mathrm{Pt}$ active sites might accelerate hydrogenation, deoxygenation as well as further decomposition, while hydrogenation and deoxygenation were separated active sites on the $\mathrm{Ru}$ catalyst [22]. Moreover, $\mathrm{O}$ et al. carried out HDO reaction runs with various reaction temperatures and time [22]. The findings showed compared to the $\mathrm{Ru} / \mathrm{C}$ upgraded oils, the $\mathrm{Pt} / \mathrm{C}$ upgraded oils exhibited the lowest water, nitrogen, sulfur, and oxygen content, as well as the lowest viscosity, and the highest heating value. However, the studies by Chen et al., Bai et al. and Zhang et al., showed $\mathrm{Ru} / \mathrm{C}$ upgraded oil exhibited more improvement in properties compared to $\mathrm{Pt} / \mathrm{C}$ treated oil (e.g., higher heating value) $[14,16,17]$. Ultimately, the findings from $\mathrm{Oh}$ et al. indicate under certain reaction conditions $\mathrm{Pt} / \mathrm{C}$ can perform better than $\mathrm{Ru} / \mathrm{C}$ during bio-oil upgrading in supercritical ethanol.

\subsection{Non-precious metal catalysts}

Although precious metal catalysts have been predominantly used for bio-oil upgrading in SCFs, non-precious metal catalysts have also been tested and proven effective for improving the quality of crude bio-oil. In two different studies, Peng et al. showed aluminium silicate and the HZSM-5 catalyst played an essential role in upgrading crude bio-oil in supercritical ethanol $[29,30]$. The acidic aluminium silicate facilitated esterification and cracking reactions and the produced bio-oil exhibited higher $\mathrm{pH}$, heating value, and lower viscosity compared to the crude bio-oil, and the catalyst free upgraded bio-oil. In the second study, Peng et al. showed acidic HZSM-5 also promoted esterification reactions, and stronger acidic HZSM-5 effectively facilitated cracking of heavy components of crude bio-oil. Zhang et al. similarly reported the complete transformation of acetic acid in the supercritical ethanol and HZSM-5 system [31]. Likewise, in the catalytic bio-oil upgrading investigation by Zhang et al., the results showed complete removal of acids in the crude bio-oil after treatment with HZSM-5 supported Ni and supercritical ethanol [32]. However, Chen et al. found at low ethanol to bio-oil ratio less acid was esterified over HZSM-5 supported $\mathrm{Ru}$ compared to $\mathrm{Ru} / \mathrm{C}$ [14]. The authors concluded for non-acidic catalyst should be used at a lower mass ratio of ethanol to bio-oil for higher acid conversion. 
Bio-oil treatment with zeolites has been shown to lead to high coke yield and low upgraded oil yield. Both catalyst screening studies by Bai et al. and Zhang et al. reported that HZSM-5 and zeolite treatments led to the highest coke production lowest upgraded oil yield [16,17]. Barreiro et al. also reported a significant increase in the production of solid residue and decrease in upgraded oil yield with HZSM-5 catalyst compared to $\mathrm{Pt} / \mathrm{Al}_{2} \mathrm{O}_{3}$ [28]. Duan et al. carried out a series of catalytic hydrothermal upgrading experiments of pre-treated algal bio-oil over nine different zeolites [33]. All the zeolite catalysts reduced the production of upgraded bio-oil and most promoted more coke formation relative to the noncatalytic treatment. The results from Cheng et al.'s bio-oil upgrading study in supercritical methanol also demonstrated bio-oil upgrading with HZSM-5 led to the lowest biofuel yield and highest coke yield out of the six varied catalytic conditions [34]. Zhang et al. compared catalytic bio-oil upgrading in supercritical ethanol over various $\mathrm{Ni}$ supported catalysts and found the highest coke yield was obtained with Ni/HZSM-5 [32]. Duan et al. suggested the ease of coking and cracking of the zeolites are possible reasons for the reduced production of upgraded bio-oil [33]. In addition, despite the low oil yield, Cheng et al. reported that the content of desirable hydrocarbons in biofuel produced by HZSM-5 based catalysts increased compared to the raw bio-oil [34].

Zhang et al. found processing over HZSM-5-supported catalysts results in less high-molecular-weight components with aromatic groups [15]. Cheng et al. found similar results as HZSM-5 and supercritical methanol upgraded oil exhibited reduced content of phenols compared to raw biooil [34]. Similarly, Duan et al. found the presence of HZSM-5 effectively promotes the cracking of macromolecules in the bio-oil and conversion to materials with lowboiling-point fractions [33].

In some cases, zeolite catalysts can provide similar or higher improvement in the elemental composition of biooil relative to precious metal catalysts. For example, Zhang et al. showed zeolite upgraded oil had lower nitrogen content than $\mathrm{Pt} / \mathrm{C}$ and $\mathrm{Pd} / \mathrm{C}$ upgraded oils [17]. Likewise, Bai et al. found HZSM-5 upgraded oil had lower nitrogen content than all the precious metal catalyst treated oils [16]. Duan et al. also reported HZSM-5 with a low Si/Al molar ratio provided good performance for denitrogenation [33]. Moreover, Barreiro et al. reported HZSM-5 and SCW upgraded biocrude from scenedesmus almeriensis algae obtained the lowest $\mathrm{O} / \mathrm{C}$ ratios compared to $\mathrm{Pt} / \mathrm{Al}_{2} \mathrm{O}_{3}$ [28].

The studies by Bai et al. and Zhang et al. found using activated carbon for upgrading biocrude in subcritical and $\mathrm{SCW}$, respectively, produced an upgraded bio-oil with lower nitrogen and oxygen content than the uncatalyzed upgraded oil $[16,17]$. The authors suggested the carbon might be responsible for denitrogenation (by adsorption rather than catalytic reaction) and deoxygenation. Additionally, both studies showed activated carbon generated an upgraded oil yield comparable to that of $\mathrm{Pt} / \mathrm{C}$ upgraded oil. Likewise, the results from $\mathrm{Xu}$ et al. showed similar upgraded oil yields were achieved with bio-oil upgraded in $\mathrm{Ru}$ mixed with $\mathrm{Pt} / \mathrm{C}$ and $\mathrm{Ru}$ mixed with activated carbon [24]. Zhang et al. also found the activated carbon led to lower coke yield relative to the coke yield with precious metal catalyst treatments [17]. Duan et al. compared the performance of several activated carbons and $\mathrm{Ru} / \mathrm{C}$ during catalytic bio-oil upgrading in SCW [20]. All the activated carbons exhibited higher desulfurization capability compared to $\mathrm{Ru} / \mathrm{C}$, which was confirmed by the lower sulfur content in all the activated carbon upgraded bio-oils relative to the $\mathrm{Ru} / \mathrm{C}$ upgraded oil. Additionally, four out of the six activated carbons facilitated greater nitrogen removal than $\mathrm{Ru} / \mathrm{C}$. Interestingly, the bio-oil upgraded with bamboo stem derived activated carbon obtained a higher heating value and hydrogen content and lower nitrogen and sulfur content than the $\mathrm{Ru} / \mathrm{C}$ upgraded oil. This demonstrates that activated carbons can be used as an inexpensive alternative to $\mathrm{Ru} / \mathrm{C}$ to generate a liquid fuel that has similar properties to those of hydrocarbon fuels derived from fossil fuel resources.

Nickel based catalysts are one of the most commonly used non-precious metal catalysts in the bio-oil upgrading studies reviewed in this report. Shi et al. investigated biooil upgrading over $\mathrm{Ni} / \mathrm{ZrO}_{2}$ in supercritical cyclohexane and reported its stability and effectiveness in catalysing several reactions including hydrogenation, and decarbonylation [35]. Similarly, Zhang et al. utilised $\mathrm{Ni} / \mathrm{SiO}_{2}-\mathrm{ZrO}_{2}$ catalyst and supercritical ethanol to upgrade bio-oil and reported the catalysts ability to facilitate complete removal of acids and aldehydes and increase the esters, higher heating value, and $\mathrm{pH}$ value [32]. In another study by Zhang et al., Ni based catalyst demonstrated excellent resistance to coking and the $\mathrm{Ni} / \mathrm{MgO}$ catalyst generated an upgraded oil yield over $80 \%$ [36]. The author also found the complete removal of organic acids over the $20 \mathrm{Ni} / \mathrm{MgO}$ catalyst. The results from Bai et al. also showed $\mathrm{Ni} / \mathrm{SiO}_{2}-\mathrm{Al}_{2} \mathrm{O}_{3}$ generated the second-largest upgraded oil yield and the lowest coke yield out of the fifteen catalytic conditions examined [16].

Many studies have incorporated cobalt into catalytic biooil upgrading in SCFs $[16,17,21,24,37,38]$. Cheng et al. used non-sulfided $\mathrm{Fe}-\mathrm{Co} / \mathrm{SiO}_{2}$ and supercritical methanol to upgrade raw bio-oil and reported that the bimetallic $\mathrm{Fe}$ $\mathrm{Co} / \mathrm{SiO}_{2}$ catalysts resulted in better $\mathrm{HDO}$ performance than monometallic $\mathrm{Fe} / \mathrm{SiO}_{2}$ or $\mathrm{Co} / \mathrm{SiO}_{2}$ catalysts due to the synergistic effect of $\mathrm{Fe}$ and $\mathrm{Co}$ on the $\mathrm{SiO}_{2}$ support [37]. In another study, Cheng et al. used bifunctional Co-Zn/HZSM-5 to upgrade bio-oil and found the bimetallic catalyst increased biofuel yields and hydrocarbons contents in biofuels compared to monometallic Co/HZSM-5 and Zn/HZSM-5 catalysts [38]. Xu et al. reported the $\mathrm{Ru} / \mathrm{C}+\mathrm{Co}-\mathrm{Mo} / \mathrm{Al}_{2} \mathrm{O}_{3}$ catalyst produced the lowest coke yield compared to eleven other catalytic conditions [24]. Moreover, the combination of $\mathrm{Ru} / \mathrm{C}$ with 
the Co-Mo based catalyst produced higher yields of upgraded oil compared to that obtained with $\mathrm{Ru} / \mathrm{C}$ alone. Likewise, Zhang et al. found of all the catalysts examined in the catalyst screening study, the $\mathrm{Co}-\mathrm{Mo} / \gamma-\mathrm{Al}_{2} \mathrm{O}_{3}$ catalyst generated the highest upgraded oil yield, and lower coke yield than $\mathrm{C}$ based $\mathrm{Ru}, \mathrm{Pd}$ and $\mathrm{Pt}$ [17]. Similarly, Bai et al. showed the upgraded oil yield with $\mathrm{CoMo} / \gamma-\mathrm{Al}_{2} \mathrm{O}_{3}$ exceeded that with $\mathrm{Pt} / \mathrm{C}$ and $\mathrm{Pd} / \mathrm{C}$ catalysts and the second-lowest coke yield was observed with this catalyst [16]. Ahmadi et al. investigated the effects of CoMo catalysts on HDO of bio-oil in supercritical ethanol [21]. The results showed CoMo/MCM-41 catalyst produced a high oil fraction which was comparable to $\mathrm{Ru} / \mathrm{C}$ treatment. Additionally, the composition of the light oil produced from the CoMo catalysts where reportedly comparable to that of the light oil obtained with the $\mathrm{Ru} / \mathrm{C}$ catalyst.

The catalyst screening studies by Zhang et al. and Bai et al. effectively demonstrate the comparable results of biooil upgrading with precious metals and less commonly used ordinary catalysts in sub- and SCW, respectively [16,17]. Zhang et al. showed $\mathrm{Mo}_{2} \mathrm{C}$ upgraded oils exhibited higher oil yields than all the precious metal catalysts, and $\mathrm{MoS}_{2}$ upgraded bio-oil oil had higher oil yield than $\mathrm{Pt} / \mathrm{C}$ and $\mathrm{Pd} / \mathrm{C}$ [17]. In addition, both catalysts generated lower coke yields than $\mathrm{C}$ supported $\mathrm{Ru}, \mathrm{Pd}$, and Pt. Likewise, Bai et al. demonstrated $\mathrm{Mo}_{2} \mathrm{C}$ upgraded oils obtained higher oil yield than $\mathrm{Pt} / \mathrm{C}$ and $\mathrm{Pd} / \mathrm{C}$ treated oils and lower coke yield than all the precious metal catalysts [16]. $\mathrm{Xu}$ et al. showed mixing $\mathrm{Ru} / \mathrm{C}$ with $\mathrm{Mo}_{2} \mathrm{C}$ led to the highest oil yield compared to mixing with any other catalyst including various precious metal catalysts [24].

Another less frequently utilised catalyst for bio-oil upgrading in SCFs is alumina. As an active metal catalyst, alumina has repeatedly shown good deoxygenation activity. Bai et al. found alumina upgraded oil exhibited lower oxygen content than $\mathrm{Pd} / \mathrm{C}$ and $\mathrm{Pt} / \mathrm{C}$ upgraded oils [16]. Similarly, $\mathrm{Xu}$ et al. showed mixing $\mathrm{Ru} / \mathrm{C}$ with alumina led to deoxygenation and denitrogenation activities equivalent to $\mathrm{Ru} / \mathrm{C}$ mixed with carbon-supported noble metal catalysts [24]. The authors in this study suggested that carbon or alumina is primarily responsible for the denitrogenation and deoxygenation, whereas noble metals play a smaller role, possibly by adsorption rather than catalytic reaction.

Overall, non-precious metal catalysts have shown activities comparable to that of the precious metal catalysts and they are promising inexpensive catalytic materials for upgrading bio-oils. However, these ordinary catalysts provide limited improvement in the quality of the bio-oil when compared to precious metal catalysts. For example, Tang et al. examined the upgrading of bio-oil and pyrolytic lignin through cracking and hydrotreatment in supercritical ethanol using various catalytic conditions $[12,18]$. The findings highlighted that although ordinary catalysts such as $\mathrm{ZrO}_{2} / \mathrm{SBA}-15$ ( $\mathrm{Zr}$ ) and $\mathrm{SO}_{4}{ }^{2-} / \mathrm{ZrO}_{2} / \mathrm{SBA}-15$ (SZr) exhibit high cracking capabilities, these catalysts are prone to promote polymerisation reactions, while the $\mathrm{Ru}$ catalysts could promote hydrocracking and inhibit polymerisation [18]. Thus, as stated by Bridgwater, when approaching bio-oil upgrading, it is important to identify which characteristic or characteristics require modification [1]. Consequently, the relevant catalyst can be appropriately selected to meet the product bio-oil specification.

\section{Non-catalytic bio-oil upgrading in SCF}

Non-catalytic bio-oil upgrading using SCFs has been extensively researched and proved to be a promising alternative to catalytic bio-oil upgrading processes. The challenges associated with catalytic bio-oil upgrading processes (i.e., expensive precious metal catalyst and external $\mathrm{H}_{2}$ addition, the possibility of catalyst deactivation due to contaminants in crude bio-oil and coking on active sites) are not encountered with SCF upgrading [9,21,39]. Thus, SCFs can be effectively used to upgrade crude biooil without a catalyst.

\subsection{Non-catalytic bio-oil upgrading in supercritical ethanol}

Prajitno et al. carried out non-catalytic, non-external $\mathrm{H}_{2}$ bio-oil upgrading in supercritical ethanol [39]. The unique reactivity associated with supercritical ethanol such as hydrogen donation, esterification, alcoholysis, cracking and alkylation, effectively decreased the TAN, water, oxygen contents and increased the bio-oil yield, carbon, hydrogen contents, and HHV. The authors concluded, the bio-oil upgraded at $400^{\circ} \mathrm{C}$ demonstrated comparable performance to heavy fuel oil in terms of the gas temperature distribution and heat flux produced. Thus, can be considered for utilisation as boiler combustion fuel.

In the bio-oil upgrading study by Dang et al., the distribution of ethers in the product indicated to the participation of supercritical ethanol in aldolization and etherification reactions [26]. Chen et al. also reported that the increase in $\mathrm{pH}$ value after upgrading was mainly due to the esterification of acetic acid and ethanol [14]. Similarly, studies by Peng et al. and Kim et al. found supercritical ethanol functioned as both a reaction medium and reactant; as esterification occurred without a catalyst in the supercritical conditions $[10,29,30]$. Yang et al. also reported on the esterification between acids and ethanol during HDO of bio-oil in supercritical ethanol [40]. Moreover, Peng et al. identified a high relative content of ethanol related compounds in the produced bio-oil, such as $18.53 \%$ of 1,1-diethoxy ethane, which suggests ethanol participated in further reactions besides esterification [30]. However, the authors established that although the quality (i.e., higher $\mathrm{pH}$ and heating value) of the catalyst-free upgraded bio-oil was higher than that of crude bio-oil, the catalytically upgraded bio-oil generally performed best 
[29]. Zhang et al. also showed the role of the supercritical ethanol solvent was extended to reactant [36]. This was confirmed when a part of ethanol was transferred into the upgraded oil via esterification and alkylation. The results also showed that bio-oil esterification with supercritical ethanol is more efficient than with subcritical conditions.

Furthermore, Zhang et al. investigated bio-oil upgrading with supercritical ethanol and found an $11.93 \%$ decrease in acid content and a $6.45 \%$ increase in ester content after the upgrading process without catalyst addition [32]. These results suggested that organic acids in the bio-oil can be converted into esters via esterification without any catalyst in supercritical ethanol. It should be noted that with the addition of catalysts the esterification reaction was further enhanced and with $20 \mathrm{Ni} / \mathrm{HZSM}-5$ catalyst, the acids were completely removed. Moreover, the authors compared upgrading bio-oil without ethanol and found the yield of solid residues and the acid content significantly decreased with the addition of supercritical ethanol. Zhang et al. explained that the coke formation was suppressed due to the excellent dissolubility of supercritical ethanol [32]. Zhang et al. also reported that ethanol has a long alkyl chain which can dissolve higher molecular-weight products, this led to less solid products after bio-oil upgrading [15]. Moreover, ethanol acts as a capping agent which can prevent the re-polymerisation which led to the reduced coke yield [32]. Furthermore, the esterification of bio-oil under supercritical conditions proved more efficient than with liquid or subcritical ethanol. Like Zhang X. et al., Zhang Q. et al. showed carboxylic acids in crude bio-oil can be esterified with supercritical ethanol and 100\% conversion of acetic acid was found after $30 \mathrm{~min}[31,32]$.

Tang et al. reported bio-oil upgraded with supercritical ethanol alone exhibited the highest $\mathrm{pH}$ value [12]. However, it also possessed higher water content, lower oil yield, and heating value compared to PdSZr and SZr upgraded oil in supercritical ethanol [12]. A further study by Tang et al. achieved similar findings [18]. The supercritical ethanol upgraded oil exhibited improved qualities, e.g., higher oil yield, heating value and lower solid yield than $\mathrm{Zr}$ and SZr catalyst treated bio-oils, as well as, lower water content than RuSZr and SZr catalyst treated bio-oils [18]. However, the Ru based catalysts effectively converted the pyrolytic lignin to stable monomers such as esters relative to non-catalytic, $\mathrm{Zr}$ or $\mathrm{SZr}$ catalytic conditions. In another bio-oil upgrading study, the authors showed similar results, where uncatalyzed upgraded oil exhibited higher oil yield, and lower solid and water yield than SZr upgraded oil [19]. These results indicate that although supercritical ethanol can provide elements of upgrading, the combination of supercritical ethanol and catalyst further enhances the upgrading process. Moreover, precious metal catalysts significantly enhance the bio-oil upgrading in supercritical ethanol whereas ordinary catalysts provide a limited advantage compared to supercritical ethanol alone.
4.2 Non-catalytic bio-oil upgrading in supercritical methanol

The research by Omar et al. included a non-catalytic upgrading of fast pyrolysis bio-oil using supercritical methanol, ethanol and isopropanol conditions, respectively [41]. The results showed supercritical methanol treatment of the crude bio-oil resulted in the complete removal of acids and a significant increase in esters. Consequently, the $\mathrm{pH}$ of the crude bio-oil increased from 2.39 to 4.04 after the supercritical methanol reaction. The authors concluded that ester formation could be the main deacidification process for reducing the acidity of the bio-oil.

Cheng et al. found supercritical methanol promoted hydrogenation and esterification reactions over $\mathrm{Fe}-\mathrm{Co} /$ $\mathrm{SiO}_{2}$ catalyst during the bio-oil HDO process [37]. This improved the contents of desirable hydrocarbons and esters in the product bio-oil. Moreover, supercritical methanol functioned as a hydrogen donor and promoted the HDO of unsaturated compounds during the upgrading process. In another bio-oil upgrading study by Cheng et al., the results showed a significant reduction in acids in the product oil, the authors predicted the acidic compounds were converted to esters through esterification reactions with alcohol in the supercritical methanol [34].

Li et al. upgraded low-boiling fraction (LBF) of bio-oil in supercritical methanol and reported that after $6 \mathrm{~h}$ reaction time the acids were converted into esters without catalyst addition [42]. Supercritical methanol functioned as a reaction medium and reactant by providing an acidic environment for the system and facilitating esterification of LBF of bio-oil without catalyst addition. Moreover, the esterification of LBF in supercritical methanol proceeded under the same reaction mechanism as that of catalytic esterification of LBF using liquid methanol. In another study, Li et al. examined the effects of upgrading high boiling fraction (HBF) of bio-oil under different supercritical media [27]. The findings showed as the polarity of the supercritical media increased (tetrahydrofuran $<$ ethanol $<$ methanol), a corresponding increase in the yield and decrease in the coke formation were observed. $\mathrm{Li}$ et al. explained that methanol has the strongest polarity of all monohydric alcohols and in the supercritical phase the polarity of $\mathrm{C}-\mathrm{O}$ and $\mathrm{O}-\mathrm{H}$ bonds increase, thus the apparent polarity and acidity are enhanced. This enables supercritical methanol to chemically break acid molecules into methyl esters [42]. The alcoholysis ability and esterification activity of supercritical methanol made it a promising medium for breaking chemical bonds of molecules in HBF and promoting the esterification of high boiling carboxylic acids in HBF.

However, catalytic upgrading with supercritical methanol also demonstrated zero acid content and proved more advantageous for reducing aldehyde and phenol content $[27,42]$. This is ideal as aldehyde and phenol can form carbonaceous deposits [42]. Likewise, Cheng et al. 
concluded that the bio-oil quality improvement after upgrading in supercritical methanol and Co-Zn/HZSM-5 catalyst was partly due to the long contact time of methanol solvent and bio-oil [38]. However, the incorporation of the HZSM-5 based catalysts further promoted the improvement of upgraded bio-oil quality.

Jo et al. investigated the effect of supercritical alcohols (methanol, ethanol, and isopropyl alcohol) on noncatalytic bio-oil upgrading [43]. Despite the absence of a catalyst, the yields of upgraded bio-oil were in the range of $77-85 \mathrm{wt}-\%$ and the solid residue yield was in the range of 0.3-0.7 wt-\%. Acetic acid esters were the dominant chemical species in the upgraded light-fraction bio-oil. These were predicted to be from esterification reactions between the acetic acid in the LBF bio-oil and the corresponding supercritical alcohols. However, the authors recognised that although the supercritical methanol upgrading process at $400^{\circ} \mathrm{C}$ resulted in a significant increase in the HHV and a decrease in the TAN, there was a high consumption of methanol at this high temperature. Chen et al. carried out solvent recovery and reutilisation as part of the bio-oil upgrading process to reduce the solvent consumption and costs [14]. The relative content of acids remained stable with the reutilization of ethanol and the relative content of esters increased gradually. The authors concluded that the recovery and reutilisation of ethanol was an effective method for decreasing the ratio of ethanol to bio-oil.

\subsection{Non-catalytic bio-oil upgrading in SCW}

Duan and Savage found SCW upgraded bio-oil exhibited lower $\mathrm{O} / \mathrm{C}$ and $\mathrm{N} / \mathrm{C}$ molar ratio than bio-oil upgraded in $\mathrm{SCW}$ over Pt/C catalyst [23]. Moreover, no sulphur content was detected in SCW-only treated upgraded oil [23]. Thus, deoxygenation, denitrogenation, and desulphurization reactions effectively proceeded without catalyst addition. This phenomenon was also observed in the catalyst screening study by Bai et al. [16]. In this study, bio-oil upgraded in SCW alone exhibited improvement in quality in terms of higher $\mathrm{H} / \mathrm{C}$ ratio than activated carbon, $\mathrm{Mo}_{2} \mathrm{C}$, $\mathrm{Ni} / \mathrm{SiO}_{2}-\mathrm{Al}_{2} \mathrm{O}_{3}$, and alumina catalysts, as well as, lower $\mathrm{O} / \mathrm{C}$ ratio and higher heating value than activated carbon catalyst [16]. However, the study by Duan et al. showed the TAN of the uncatalyzed upgraded oil was almost double the Pt/C upgraded oil [23]. This is unfavourable as high acid levels lead to corrosion and hinders consideration for practical application of the oil. In a further report, Duan et al. showed that bio-oil upgraded in SCW without a catalyst exhibited higher TAN, nitrogen and sulphur content, and lower carbon, hydrogen, and HHV than biooils treated with various activated carbon catalysts and SCW [20]. Moreover, the bio-oil upgraded with bamboo activated carbon exhibited a higher heating value than $\mathrm{Ru} / \mathrm{C}$. Hence, bamboo activated carbon may be considered as an inexpensive alternative that overcomes both challenges of SCF-only upgrading and precious-metal catalyst upgrading.

Isa et al. investigated upgrading bio-oil to bio-fuel using sub- and SCW [44]. The SCW conditions gave the highest bio-oil plus water yield and the lowest char yield. Moreover, the non-catalytic SCW treatment reduced the oxygen contents of the bio-oil.

In another study by Duan et al., the treated oil and coke yields with the non-catalytic upgrading process were comparable to the catalytic upgrading process [25]. SCW demonstrated effective coke control due to its ability to extract and transport potential coke precursors from the catalyst pores [25]. Moreover, minimal differences were noted in the $\mathrm{H} / \mathrm{C}$ ratio between bio-oil upgraded in SCW over $\mathrm{Pt} / \gamma-\mathrm{Al}_{2} \mathrm{O}_{3}$ and bio-oil upgraded in SCW alone [25]. Thus, SCW alone was capable of promoting hydrogenation of the crude bio-oil. However, significantly higher levels of deoxygenation, denitrogenation, and heating value were achieved with $\mathrm{Pt} / \gamma-\mathrm{Al}_{2} \mathrm{O}_{3}$ upgraded oil in $\mathrm{SCW}$ [25]. Likewise, in a further study, Duan et al. found SCW suppresses coke formation due to its solvation and dilution characteristics, but further reduced coke formation was observed with $\mathrm{Ru} / \mathrm{C}$ [20]. Another study by Duan et al. showed uncatalyzed bio-oil in SCW generated the highest bio-oil yield and one of the lowest coke yields relative to several different zeolite catalysts [33]. However, bio-oil treated with zeolite catalysts in SCW provided higher levels of hydrogenation, deoxygenation, denitrogenation, desulphurisation, and ultimately higher heating value than SCW upgraded oil alone. Similarly, Remón et al. found the presence of SCW can partially reduce the solid formation and/or favour its removal [45]. The results showed $0 \%$ coke yield and the highest liquid yield was obtained without catalyst addition. Moreover, the carboxylic acids were eliminated without catalyst addition at conditions of $450^{\circ} \mathrm{C} 260$ bar. However, the HHV without catalyst addition was lower than with the incorporation of $\mathrm{Ni}-\mathrm{Co} /$ Al-Mg catalyst.

Zhang et al. reported that non-catalytically treated biocrude in subcritical water showed higher oil yield, carbon content, and lower coke yield and water content compared to treatment with several different catalysts [17]. The subcritical water appeared to incorporate into the products fraction and demonstrated some denitrogenation of the biocrude by dissolving the nitrogen-containing compounds [17]. However, uncatalyzed upgraded oil exhibited the lowest $\mathrm{HHV}$ and $\mathrm{H} / \mathrm{C}$ molar ratio, this is unfavourable for considering the fuel for further applications.

In the algal oil upgrading study by Xu et al., the SCW physically decreased the nitrogen content in the upgraded bio-oil [24]. This was indicated by the large number of nitrogen compounds detected in the water-soluble side product. Moreover, the sulphur content was reported as undetectable using a common elemental analyser but was quantified using a coulometric titration method [24]. 
However, catalytic bio-oil upgrading in SCW achieved a higher $\mathrm{H} / \mathrm{C}$ ratio, heating value and significantly lower N/C and $\mathrm{O} / \mathrm{C}$ ratio compared to uncatalyzed upgraded oil [24]. Likewise, Remon et al. found the level of sulphur in the SCW-only treated liquid was the same as the catalytically treated bio-oil [46]. In addition, SCW-only upgraded oil exhibited higher heating value, $\mathrm{H} / \mathrm{C}$ ratio and lower $\mathrm{O} / \mathrm{C}$ ratio than $\mathrm{NiCo} / \mathrm{CNF}_{\mathrm{r}}-900$ catalysed bio-oil in $\mathrm{SCW}$. However, $\mathrm{NiCo} / \mathrm{CNF}_{\mathrm{f}}$ and $\mathrm{NiCo} / \mathrm{CNF}_{\mathrm{f}}-600$ catalysts further enhanced the heating value and hydrocarbon content and reduced the carboxylic acids in the bio-oil.

\subsection{Non-catalytic bio-oil upgrading in other SCFs}

SCFs are recognised for the unique dissolving power which is highly effective during bio-oil upgrading for increasing yield and improving the characteristics of the bio-oil. Shi et al. investigated upgrading bio-oil using supercritical cyclohexane and noted the excellent solubility of hydrogen in the SCF which led to the improvement in yield and quality of liquid hydrocarbons [35]. This was confirmed by the lower liquid hydrocarbon yield and the content of $\mathrm{C}_{8}-\mathrm{C}_{22}$ hydrocarbons with non-supercritical cyclohexane, relative to supercritical cyclohexane.

$\mathrm{Xu}$ et al. examined bio-oil upgrading using supercritical 1-butanol over $\mathrm{Ru} / \mathrm{C}$ [47]. The highest hydrogen and carbon content, HHV, $\mathrm{pH}$ and the lowest viscosity, moisture and oxygen content was achieved under these conditions relative to subcritical 1-butanol or without solvent addition. More significantly, the solid product decreased from $2.5 \%$ without solvent to $0.2 \%$ with supercritical 1-butanol which indicated to reduced coke formation in the presence of the supercritical solvent. The study demonstrated that the use of a supercritical solvent particularly enhances the quality of bio-oil. Moreover, like many studies of bio-oil upgrading in supercritical alcohol, $\mathrm{Xu}$ et al. reported the carboxylic acids were converted into their corresponding esters via esterification with 1-butanol.

Likewise, Cui et al. examined the effect of $\mathrm{scCO}_{2}$ on the esterification of acids in bio-oil and found the conversion of the acids was higher under the $\mathrm{scCO}_{2}$ conditions compared to atmospheric which indicated the promoting effect of $\mathrm{scCO}_{2}$ [48]. Moreover, $\mathrm{scCO}_{2}$ was used to upgrade the bio-oil by extraction and the $\mathrm{scCO}_{2}$ extract fraction contained higher amounts of esters and lower amounts of water and acids. Additionally, the volatile compounds were enriched into the extract fraction and this oil exhibited improved $\mathrm{pH}$, heating value and stability, thus demonstrated to be a promising fuel for further application.

\section{Conclusions}

The pro forma Table 4 shows the precious metal catalysts platinum, palladium and ruthenium are the most commonly used in the papers examined in this literature review. Additionally, methanol, ethanol, and water are frequently used as solvents for the SCF upgrading. Majority of the papers highlight the improvement in the properties and characteristics of the bio-oil after upgrading. Moreover, the supercritical solvents are consistently recognised for their active effects on the upgrading process which is more than what is observed in ordinary liquid solvent conditions. The literature review demonstrates that non-precious metal catalysts are a viable and economical alternative to expensive precious metal catalysts for bio-oil upgrading. Particularly when SCFs are used in conjunction which provide some catalyst-like activities.

Most studies of bio-oil upgrading in SCF utilise batch reactors. For future research, continuous flow reactors can be considered to increase bio-oil production efficiency and suitability for commercialisation processes. However, the high viscosity of crude bio-oil presents a technical challenge when feeding into a continuous reactor. This can be solved with SCF treatment, as the literature studies have shown bio-oil treatment with SCFs produces a bio-oil with lower viscosity, as well as higher yield and fuel quality.

Table 4 Summary of SCF bio-oil upgrading methods reported in the literature

\begin{tabular}{|c|c|c|c|c|c|c|c|c|}
\hline Feed & Solvent & Performance of SCF & Catalyst & $T /{ }^{\circ} \mathrm{C}$ & $P / \mathrm{MPa}$ & $t / \min$ & Initial $\mathrm{H}_{2} / \mathrm{MPa}$ & Ref. \\
\hline $\begin{array}{l}\text { Flash pyrolysis of pulverized } \\
\text { corn stalk }\end{array}$ & $\mathrm{CO}_{2}$ & $\begin{array}{l}\text { Higher conversions compared } \\
\text { to esterification at atmosphere } \\
\text { pressure }\end{array}$ & $\begin{array}{c}p \text {-Toluene } \\
\text { sulfonic acid }\end{array}$ & 80 & 28 & 180 & - & [48] \\
\hline $\begin{array}{l}\text { Heavy residues of fast pyrolysis } \\
\text { of rice husk (HBF) }\end{array}$ & Methanol & Promotes alcoholysis & $\begin{array}{c}\mathrm{Pt}, \mathrm{PtNi}, \mathrm{PdNi} \text { on } \\
\mathrm{Al}_{2}\left(\mathrm{SiO}_{3}\right)_{3}, \mathrm{SiO}_{2}, \mathrm{MgO}\end{array}$ & 290 & - & 300 & 2 & [27] \\
\hline $\begin{array}{l}\text { Light residues of fast pyrolysis } \\
\text { of rice husk (LBF) }\end{array}$ & Methanol & Facilitates esterification & $\begin{array}{c}\text { Pt on } \mathrm{Al}_{2}\left(\mathrm{SiO}_{3}\right)_{3}, \mathrm{C} \\
\text { and } \mathrm{MgO}\end{array}$ & 250 & $8.6-9.6$ & $\begin{array}{c}180- \\
540\end{array}$ & 1.5 & {$[42]$} \\
\hline $\begin{array}{l}\text { Bio-oil from pyrolysis of pine } \\
\text { sawdust }\end{array}$ & Methanol & $\begin{array}{l}\text { Hydrogenation and } \\
\text { esterification reactions }\end{array}$ & $\begin{array}{l}\text { Co; Zn; Co-Zn } \\
\text { on HZSM-5 }\end{array}$ & 300 & - & 300 & 3.4 & [38] \\
\hline $\begin{array}{l}\text { Bio-oil from pine sawdust } \\
\text { pyrolysis }\end{array}$ & Methanol & $\begin{array}{l}\text { Functioned as hydrogen } \\
\text { donor, promoted HDO }\end{array}$ & $\begin{array}{c}\mathrm{Fe}-\mathrm{Co} / \mathrm{SiO}_{2} \text { or } \\
\mathrm{Co} / \mathrm{HZSM}-5\end{array}$ & 300 & - & 300 & 3.45 & [37] \\
\hline $\begin{array}{l}\text { Bio-oil from pine sawdust } \\
\text { pyrolysis }\end{array}$ & Methanol & $\begin{array}{l}\text { Mainly hydrogenation } \\
\text { and esterification reactions }\end{array}$ & Fe-Ni/HZSM-5 & 300 & - & 300 & 3.4 & [34] \\
\hline
\end{tabular}


(Continued)

\begin{tabular}{|c|c|c|c|c|c|c|c|c|}
\hline Feed & Solvent & Performance of SCF & Catalyst & $T /{ }^{\circ} \mathrm{C}$ & $P / \mathrm{MPa}$ & $t / \min$ & Initial $\mathrm{H}_{2} / \mathrm{MPa}$ & Ref. \\
\hline $\begin{array}{l}\text { Low boiling fraction of bio-oil } \\
\text { from fast pyrolysis of empty palm } \\
\text { fruit bunch }\end{array}$ & Methanol & $\begin{array}{l}\text { High esterification } \\
\text { and alkylation ability }\end{array}$ & - & 400 & $\begin{array}{c}22.5- \\
46.7\end{array}$ & 30 & $1 \mathrm{MPa} \mathrm{N} 2$ & {$[43]$} \\
\hline $\begin{array}{l}\text { Pyrolysis oil of } \\
\text { Pinussylvestris L. }\end{array}$ & $\begin{array}{l}\text { Methanol, } \\
\text { Ethanol }\end{array}$ & $\begin{array}{l}\text { Increased variety of esters } \\
\text { when processing in ethanol }\end{array}$ & $\begin{array}{l}\mathrm{Pd} \text {; Pt on HZSM-5; } \\
\mathrm{SO}_{4}{ }^{2-} / \mathrm{ZrO}_{2} / \mathrm{SBA}-15\end{array}$ & 260 & $7.5-11.5$ & 180 & 2 & {$[15]$} \\
\hline $\begin{array}{l}\text { Fast pyrolysis oil of } \\
\text { rice husk }\end{array}$ & Ethanol & $\begin{array}{l}\text { Decreased phenols and } \\
\text { aldehydes during upgrading }\end{array}$ & Aluminium silicate & 260 & 7.8 & 180 & - & [29] \\
\hline $\begin{array}{l}\text { Fast pyrolysis oil of } \\
\text { rice husk }\end{array}$ & Ethanol & $\begin{array}{l}\text { Effectively removes heavy } \\
\text { components in bio-oil }\end{array}$ & $\operatorname{HZSM}-5(\mathrm{Si} / \mathrm{Al}=22)$ & $100-238$ & 260 & 180 & - & {$[30]$} \\
\hline $\begin{array}{l}\text { Flash pyrolysis oil of } \\
\text { rice husk }\end{array}$ & Ethanol & $\begin{array}{l}\text { Facilitates hydrotreatment } \\
\text { when used with catalyst }\end{array}$ & $\begin{array}{c}\mathrm{Pd} / \mathrm{SO}_{4}{ }^{2-} / \mathrm{ZrO}_{2} / \mathrm{SBA}- \\
15\end{array}$ & 280 & $8.5-10.5$ & 180 & $0-2$ & [12] \\
\hline $\begin{array}{l}\text { Pyrolytic lignin from } \\
\text { flash pyrolysis of rice husk }\end{array}$ & Ethanol & $\begin{array}{c}\text { Promotes } \\
\text { hydrocracking }\end{array}$ & $\begin{array}{l}\mathrm{Ru} / \mathrm{SO}_{4}{ }^{2-} / \mathrm{ZrO}_{2} / \mathrm{SBA}- \\
15 \text { or } \mathrm{Ru} / \mathrm{ZrO}_{2} / \mathrm{SBA}-15\end{array}$ & 260 & 9.5 & 480 & 2 & [18] \\
\hline $\begin{array}{l}\text { Fast pyrolysis oil of } \\
\text { rice husk }\end{array}$ & Ethanol & $\begin{array}{l}\text { Participation of ethanol } \\
\text { in aldolization and } \\
\text { etherification reactions }\end{array}$ & $\begin{array}{c}\mathrm{Pt} / \\
\mathrm{SO}_{4}{ }^{2-} / \mathrm{ZrO}_{2} / \mathrm{SBA}-15\end{array}$ & $260-300$ & o $7-11.8$ & 180 & $0.5,2$ & [26] \\
\hline $\begin{array}{l}\text { Bio-oil from fast pyrolysis } \\
\text { of rice husk }\end{array}$ & Ethanol & $\begin{array}{l}\text { Improved bio-oil physical } \\
\text { properties and composition } \\
\text { of organic compounds }\end{array}$ & $\begin{array}{c}\mathrm{Pt} / \mathrm{C} ; \mathrm{Pd} / \mathrm{C} ; \mathrm{Ru} / \mathrm{C} ; \mathrm{Ru} / \\
\mathrm{HZSM}-5\end{array}$ & 300 & - & 300 & 2 & [14] \\
\hline $\begin{array}{l}\text { Bio-oil from fast pyrolysis of } \\
\text { Miscanthus sinensis biomass }\end{array}$ & Ethanol & $\begin{array}{c}\text { Decreased viscosity } \\
\text { of heavy-oil }\end{array}$ & $\mathrm{Pd} / \mathrm{C}$ & $250-350$ & - & $30-60$ & 3 & [11] \\
\hline $\begin{array}{l}\text { Bio-oil from fast pyrolysis of } \\
\text { Miscanthus sinensis }\end{array}$ & Ethanol & $\begin{array}{l}\text { Converts acid in } \\
\text { bio-oil into ester }\end{array}$ & $\mathrm{Pt} / \mathrm{C} ; \mathrm{Ru} / \mathrm{C}$ & $250-350$ & - & $30-60$ & 3 & [22] \\
\hline $\begin{array}{l}\text { Bio-oil from fast pyrolysis of } \\
\text { rice husk }\end{array}$ & Ethanol & $\begin{array}{c}\text { Facilitates catalytic } \\
\text { upgrading }\end{array}$ & $\mathrm{Ni} / \mathrm{SiO}_{2}-\mathrm{ZrO}_{2}$ & 280 & - & 300 & 1.5 & [32] \\
\hline Fast pyrolysis oil of sawdust & Ethanol & $\begin{array}{l}\text { Crude bio-oil easily esterified } \\
\text { with supercritical ethanol }\end{array}$ & Zeolite & $200-250$ & 7 & 180 & - & [31] \\
\hline $\begin{array}{l}\text { Pyrolytic lignin from fast } \\
\text { pyrolysis of rice husk }\end{array}$ & Ethanol & $\begin{array}{l}\text { Enables high hydrocracking } \\
\text { activity of supported metal }\end{array}$ & $\begin{array}{l}\text { SBA-15; Zr; RuZr; } \\
\text { SZr; RuSZr }\end{array}$ & 260 & 9.5 & 480 & 2 & [19] \\
\hline $\begin{array}{l}\text { Bio-oil from fast pyrolysis } \\
\text { of yellow poplar wood }\end{array}$ & Ethanol & $\begin{array}{c}\text { Deoxygenation and } \\
\text { increased light oil yields }\end{array}$ & $\mathrm{Pd} / \mathrm{C}$ & $250-370$ & - & $40-120$ & 3 & [10] \\
\hline $\begin{array}{l}\text { Bio-oil from fast pyrolysis } \\
\text { of empty palm fruit bunch }\end{array}$ & Ethanol & $\begin{array}{l}\text { Hydrogen donation } \\
\text { ability }\end{array}$ & - & $300-400$ & $\begin{array}{c}16.8- \\
41.3\end{array}$ & $30-120$ & $1 \mathrm{MPa} \mathrm{N}_{2}$ & [39] \\
\hline $\begin{array}{l}\text { Bio-oil from hydrothermally } \\
\text { liquefied dried cornstalk powder }\end{array}$ & Ethanol & $\begin{array}{l}\text { Promotes esterification } \\
\text { reactions }\end{array}$ & $\begin{array}{l}\text { Bimetallic ammonium } \\
\text { nickel molybdate }\end{array}$ & $280-370$ & - & 60 & 4 & [40] \\
\hline Fast pyrolysis of rice husk & Ethanol & $\begin{array}{c}\text { Enables esterification } \\
\text { of bio-oil }\end{array}$ & $\mathrm{Ni} / \mathrm{MgO}$ & 280 & - & 300 & 1.5 & [36] \\
\hline $\begin{array}{l}\text { Pyrolysis oil from hardwood } \\
\text { sawdust fast pyrolysis }\end{array}$ & Ethanol & $\begin{array}{l}\text { Effective solvent-reduced the } \\
\text { molecular weight of bio-oil }\end{array}$ & $\mathrm{Ru} / \mathrm{C}$ & 300 & - & 180 & 10 & [49] \\
\hline Hardwood sawdust fast pyrolysis oil & Ethanol & $\begin{array}{l}\text { Increases } \mathrm{H} / \mathrm{C} \text { ratio and } \\
\text { reduces } \mathrm{O} / \mathrm{C} \text { ratio in bio-oil }\end{array}$ & $\begin{array}{l}\text { CoMo catalysts sup- } \\
\text { ported on various } \\
\text { nanostructured materi- } \\
\text { als; } \mathrm{Ru} / \mathrm{C}\end{array}$ & 350 & 22.5 & 180 & 5 & [21] \\
\hline Fast pyrolysis of pine sawdust & 1-Butanol & $\begin{array}{l}\text { Decreases oxygen content, } \\
\text { increases heating value in } \\
\text { upgraded bio-oil }\end{array}$ & $\mathrm{Ru} / \mathrm{C}$ & $250-300$ & $08.8-11.5$ & 180 & 2 & [47] \\
\hline Bio-oil from HTL of cornstalks & $\begin{array}{l}\text { Cyclohex- } \\
\text { ane }\end{array}$ & $\begin{array}{l}\text { Improved the yield and the } \\
\text { quality of liquid hydro- } \\
\text { carbons }\end{array}$ & $\mathrm{Ni} / \mathrm{ZrO}_{2}$ & 300 & - & 240 & 5 & {$[35]$} \\
\hline $\begin{array}{l}\text { Crude algal bio-oil from } \\
\text { liquefaction of microalga paste }\end{array}$ & Water & $\begin{array}{l}\text { Higher heating value and } \\
\text { lower acid number than } \\
\text { the crude bio-oil }\end{array}$ & $\mathrm{Pt} / \mathrm{C}$ & 400 & - & 240 & 3.4 & [23] \\
\hline $\begin{array}{l}\text { Crude algal bio-oil from } \\
\text { liquefaction of microalga paste }\end{array}$ & Water & $\begin{array}{l}\text { Cracking of the longer } \\
\text { chain alkanes }\end{array}$ & $\mathrm{Pd} / \mathrm{C}$ & 400 & - & $60-480$ & 3.4 & [13] \\
\hline
\end{tabular}




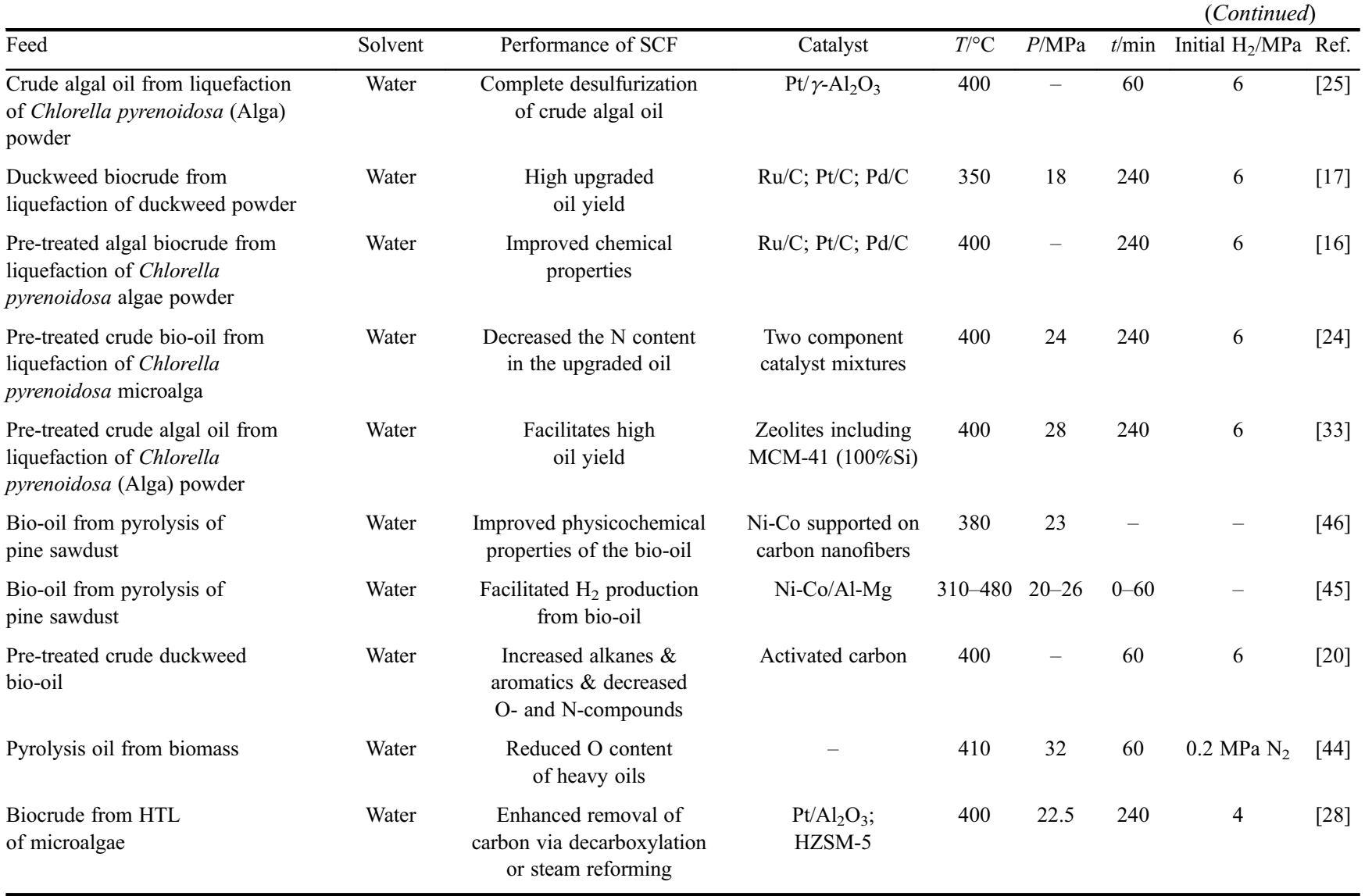

Open Access This article is licensed under a Creative Commons Attribution 4.0 International License, which permits use, sharing, adaptation, distribution and reproduction in any medium or format, as long as you give appropriate credit to the original author(s) and the source, provide a link to the Creative Commons licence, and indicate if changes were made. The images or other third party material in this article are included in the article's Creative Commons licence, unless indicated otherwise in a credit line to the material. If material is not included in the article's Creative Commons licence and your intended use is not permitted by statutory regulation or exceeds the permitted use, you will need to obtain permission directly from the copyright holder. To view a copy of this licence, visit http://creativecommons.org/licenses/by/4.0/.

\section{References}

1. Brown R C, Jenkins B M, Baxter L L, Koppejan J, Bain R L, Broer K, Dayton D C, Turk B, Gupta R, Venderbosch R H, et al. Thermochemical Processing of Biomass Conversion into Fuels, Chemicals and Power. New Jersey: John Wiley \& Sons, Ltd., 2011, 157-188

2. Holm-Nielsen J B, Ehimen E A. Biomass Supply Chains for Bioenergy and Biorefining. Cambridge: Woodhead Publishing, 2016, 3-13

3. Bridgwater A V. Review of fast pyrolysis of biomass and product upgrading. Biomass and Bioenergy, 2012, 38: 68-94

4. Demirbas A. Competitive liquid biofuels from biomass. Applied Energy, 2011, 88(1): 17-28

5. Oasmaa A, Czernik S. Fuel oil quality of biomass pyrolysis oils state of the art for the end users. Energy \& Fuels, 1999, 13(4): 914-921

6. Xiu S, Shahbazi A. Bio-oil production and upgrading research: A review. Renewable \& Sustainable Energy Reviews, 2012, 16(7): 4406-4414

7. Jessop P G, Leitner W. Chemical Synthesis Using Supercritical Fluids. New Jersey: Wiley, 2008, 1-65

8. Baiker A. Supercritical fluids in heterogeneous catalysis. Chemical Reviews, 1999, 99(2): 453-473

9. Tan K T, Lee K T. A review on supercritical fluids (SCF) technology in sustainable biodiesel production: Potential and challenges. Renewable \& Sustainable Energy Reviews, 2011, 15(5): 2452-2456

10. Kim T, Oh S, Kim J, Choi I C J W, Choi J W. Study on the hydrodeoxygenative upgrading of crude bio-oil produced from woody biomass by fast pyrolysis. Energy, 2014, 68: 437-443

11. Oh S, Hwang H, Choi H S, Choi J W. Investigation of chemical modifications of micro- and macro-molecules in bio-oil during hydrodeoxygenation with $\mathrm{Pd} / \mathrm{C}$ catalyst in supercritical ethanol. Chemosphere, 2014, 117(1): 806-814

12. Tang Z, Lu Q, Zhang Y, Zhu X, Guo Q. One step bio-oil upgrading through hydrotreatment, esterification, and cracking. Industrial \& Engineering Chemistry Research, 2009, 48(15): 6923-6929

13. Duan P, Savage P E. Catalytic hydrotreatment of crude algal bio-oil in supercritical water. Applied Catalysis B: Environmental, 2011, 104(1-2): 136-143

14. Chen W, Luo Z, Yu C, Li G, Yang Y, Zhang H. Upgrading of bio-oil in supercritical ethanol: Catalysts screening, solvent recovery and 
catalyst stability study. Journal of Supercritical Fluids, 2014, 95: 387-393

15. Zhang J, Luo Z, Dang Q, Wang J, Chen W. Upgrading of bio-oil over bifunctional catalysts in supercritical monoalcohols. Energy \& Fuels, 2012, 26(5): 2990-2995

16. Bai X, Duan P, Xu Y, Zhang A, Savage P E. Hydrothermal catalytic processing of pretreated algal oil: A catalyst screening study. Fuel, 2014, 120: 141-149

17. Zhang C, Duan P, Xu Y, Wang B, Wang F, Zhang L. Catalytic upgrading of duckweed biocrude in subcritical water. Bioresource Technology, 2014, 166: 37-44

18. Tang Z, Zhang Y, Guo Q. Catalytic hydrocracking of pyrolytic lignin to liquid fuel in supercritical ethanol. Industrial \& Engineering Chemistry Research, 2010, 49(5): 2040-2046

19. Yao Q, Tang Z, Guo J H, Zhang Y, Guo Q X. Effect of catalyst properties on hydrocracking of pyrolytic lignin to liquid fuel in supercritical ethanol. Chinese Journal of Chemical Physics, 2015, 28(2): 209-216

20. Duan P, Zhang C, Wang F, Fu J, Lü X, Xu Y, Shi X. Activated carbons for the hydrothermal upgrading of crude duckweed bio-oil. Catalysis Today, 2016, 274: 73-81

21. Ahmadi S, Yuan Z, Rohani S, Xu C. Effects of nano-structured CoMo catalysts on hydrodeoxygenation of fast pyrolysis oil in supercritical ethanol. Catalysis Today, 2016, 269: 182-194

22. Oh S, Hwang H, Choi H S, Choi J W. The effects of noble metal catalysts on the bio-oil quality during the hydrodeoxygenative upgrading process. Fuel, 2015, 153: 535-543

23. Duan P, Savage P E. Upgrading of crude algal bio-oil in supercritical water. Bioresource Technology, 2011, 102(2): 18991906

24. Xu Y, Duan P, Wang B. Catalytic upgrading of pretreated algal oil with a two-component catalyst mixture in supercritical water. Algal Research, 2015, 9: 186-193

25. Duan P, Bai X, Xu Y, Zhang A, Wang F, Zhang L, Miao J. Catalytic upgrading of crude algal oil using platinum/gamma alumina in supercritical water. Fuel, 2013, 109: 225-233

26. Dang Q, Luo Z, Zhang J, Wang J, Chen W, Yang Y. Experimental study on bio-oil upgrading over $\mathrm{Pt} / \mathrm{SO}_{4}{ }^{2-} / \mathrm{ZrO}_{2} / \mathrm{SBA}-15$ catalyst in supercritical ethanol. Fuel, 2013, 103: 683-692

27. Li W, Pan C, Sheng L, Liu Z, Chen P, Lou H Z X, Zheng X. Upgrading of high-boiling fraction of bio-oil in supercritical methanol. Bioresource Technology, 2011, 102(19): 9223-9228

28. Barreiro D L, Gomez B R, Ronsse F, Hornung U, Kruse A, Prins W. Heterogeneous catalytic upgrading of biocrude oil produced by hydrothermal liquefaction of microalgae: State of the art and own experiments. Fuel Processing Technology, 2016, 148: 117-127

29. Peng J, Chen P, Lou H, Zheng X. Upgrading of bio-oil over aluminum silicate in supercritical ethanol. Energy \& Fuels, 2008, 22 (5): 3489-3492

30. Peng J, Chen P, Lou H, Zheng X. Catalytic upgrading of bio-oil by HZSM-5 in sub- and super-critical ethanol. Bioresource Technology, 2009, 100(13): 3415-3418

31. Zhang Q, Xu Y, Li Y, Wang T, Zhang Q, Ma L, He M L K, Li K. Investigation on the esterification by using supercritical ethanol for bio-oil upgrading. Applied Energy, 2015, 160: 633-640
32. Zhang X, Chen L, Kong W, Wang T, Zhang Q, Long J, Xu Y, Ma L. Upgrading of bio-oil to boiler fuel by catalytic hydrotreatment and esterification in an efficient process. Energy, 2015, 84: 83-90

33. Duan P, Xu Y, Wang F, Wang B, Yan W. Catalytic upgrading of pretreated algal bio-oil over zeolite catalysts in supercritical water. Biochemical Engineering Journal, 2016, 116: 105-112

34. Cheng S, Wei L, Julson J, Muthukumarappan K, Kharel P R. Upgrading pyrolysis bio-oil to hydrocarbon enriched biofuel over bifunctional Fe-Ni/HZSM-5 catalyst in supercritical methanol. Fuel Processing Technology, 2017, 167: 117-126

35. Shi W, Gao Y, Song S, Zhao Y. One-pot conversion of bio-oil to diesel- and jet-fuel-range hydrocarbons in supercritical cyclohexane. Industrial \& Engineering Chemistry Research, 2014, 53(28): $11557-11565$

36. Zhang X, Zhang Q, Wang T, Li B, Xu Y, Ma L. Efficient upgrading process for production of low quality fuel from bio-oil. Fuel, 2016, 179: $312-321$

37. Cheng S, Wei L, Julson J, Rabnawaz M. Upgrading pyrolysis bio-oil through hydrodeoxygenation (HDO) using non-sulfided $\mathrm{Fe}-\mathrm{Co} / \mathrm{SiO}_{2}$ catalyst. Energy Conversion and Management, 2017, 150: 331-342

38. Cheng S, Wei L, Julson J, Muthukumarappan K, Kharel P R. Upgrading pyrolysis bio-oil to biofuel over bifunctional $\mathrm{Co}-\mathrm{Zn}$ / HZSM-5 catalyst in supercritical methanol. Energy Conversion and Management, 2017, 147: 19-28

39. Prajitno H, Insyani R, Park J, Ryu C, Kim J. Non-catalytic upgrading of fast pyrolysis bio-oil in supercritical ethanol and combustion behavior of the upgraded oil. Applied Energy, 2016, 172: $12-22$

40. Yang T, Jie Y, Li B, Kai X, Yan Z, Li R. Catalytic hydrodeoxygenation of crude bio-oil over an unsupported bimetallic dispersed catalyst in supercritical ethanol. Fuel Processing Technology, 2016, 148: 19-27

41. Omar S, Alsamaq S, Yang Y, Wang J. Production of renewable fuels by blending bio-oil with alcohols and upgrading under supercritical conditions. Frontiers of Chemical Science and Engineering, 2019, 13(4): 702-717

42. Li W, Pan C, Zhang Q, Liu Z, Peng J, Chen P, Lou H Z X, Zheng X. Upgrading of low-boiling fraction of bio-oil in supercritical methanol and reaction network. Bioresource Technology, 2011, 102(7): 4884-4889

43. Jo H, Prajitno H, Zeb H, Kim J. Upgrading low-boiling-fraction fast pyrolysis bio-oil using supercritical alcohol: Understanding alcohol participation, chemical composition, and energy efficiency. Energy Conversion and Management, 2017, 148: 197-209

44. Isa K M, Snape C E, Uguna C, Meredith W, Deng H. Pyrolysis oil upgrading in high conversions using sub- and supercritical water above $400^{\circ} \mathrm{C}$. Journal of Analytical and Applied Pyrolysis, 2016, 119: $180-188$

45. Remón J, Arcelus-Arrillaga P, García L, Arauzo J. Production of gaseous and liquid bio-fuels from the upgrading of lignocellulosic bio-oil in sub- and supercritical water: Effect of operating conditions on the process. Energy Conversion and Management, 2016, 119: 14-36

46. Remon J, Arauzo J, Garcia L, Arcelus-Arrillaga P, Millan M, Suelves I P J L, Pinilla J L. Bio-oil upgrading in supercritical water 
using Ni-Co catalysts supported on carbon nanofibres. Fuel Processing Technology, 2016, 154: 178-187

47. Xu X, Zhang C, Zhai Y, Liu Y, Zhang R, Tang X. Upgrading of biooil using supercritical 1-butanol over a $\mathrm{Ru} / \mathrm{C}$ heterogeneous catalyst: Role of the solvent. Energy \& Fuels, 2014, 28(7): 4611-4621

48. Cui H Y, Wang J H, Wei S Q, Zhuo S P, Li Z H, Wang L H, Yi W.
Upgrading bio-oil by esterification under supercritical $\mathrm{CO}_{2}$ conditions. Journal of Fuel Chemistry and Technology, 2010, 38(386): 673-678

49. Ahmadi S, Reyhanitash E, Yuan Z, Rohani S, Xu C. Upgrading of fast pyrolysis oil via catalytic hydrodeoxygenation: Effects of type of solvents. Renewable Energy, 2017, 114: 376-382 